(200)

G

no. 2182 


\title{
Trap-Efficiency Study, Highland Creek Flood-Retarding Reservoir Near Kelseyville, California, Water Years 1966-77
}

\author{
By L. F. TRUJILLO
}

Prepared in cooperation with the U.S. Department of Agriculture, Soil Conservation Service

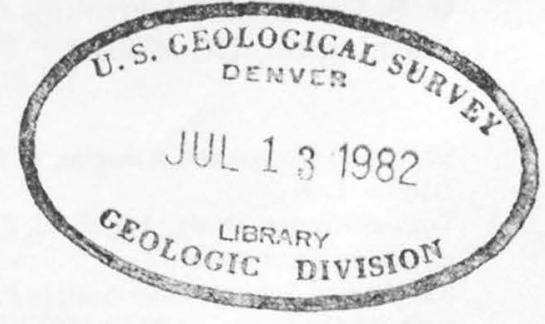

U.S. GEOLOGICAL SURVEY WATER-SUPPLY PAPER 2182 


\title{
UNITED STATES DEPARTMENT OF THE INTERIOR
}

\author{
JAMES G. WATT, Secretary \\ GEOLOGICAL SURVEY \\ Dallas L. Peck, Director
}

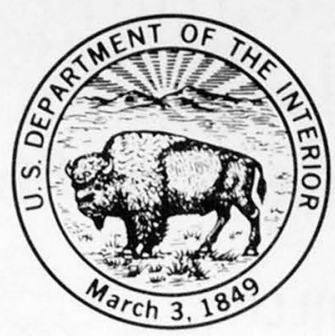

For sale by the Superintendent of Documents

U. S. Government Printing Office

Washington, DC 20402

\section{Library of Congress Cataloging in Publication Data}

Trujillo, L. F.

Trap-efficiency study, Highland Creek flood-retarding reservoir near Kelseyville, California, Water Years $1966-77$.

(Geological Survey Water-Supply Paper 2182)

Supt. of Docs. no. : I 19.13:2182

1. Flood dams and reservoirs-California-Highland Creek-Testing. 2. Highland Creek Reservoir, Calif. 3. Highland Creek Dam, Calif. I. United States Soil Conservation Service. II. Title. III. Series: United States Geological Survey Water-Supply Paper 2182. 


\title{
CONTENTS
}

\author{
Abstract 1 \\ Introduction 1 \\ Characteristics of the drainage basin 1 \\ Description of reservoir and dam 4 \\ Method of investigation 4 \\ Runoff 4 \\ Suspended sediment $\mathbf{5}$ \\ Reservoir surveys 7 \\ Results of investigation $\mathbf{1 0}$ \\ Runoff data 10 \\ Sediment data 11 \\ Reservoir survey data $\mathbf{1 2}$ \\ Computation of trap efficiency $\mathbf{1 4}$ \\ Summary 14 \\ References cited 14
}

\section{FIGURES}

1. Index map 2

2. Map showing location and features of Highland Creek Reservoir and drainage basin 3

3-6. Photographs showing:

3. Highland Creek Dam and outlet structure 4

4. Highland Creek Reservoir and principal outlet structure $\mathbf{4}$

5. Gaging station on Highland Creek above Highland Creek Dam $\mathbf{5}$

6. Outflow sampling site at outlet tunnel of Highland Creek Dam 6

7. Graph showing relation between suspended-sediment discharge and water discharge, Highland Creek above Highland Creek Dam, 1966- 68 water years 7

\section{TABLES}

1. Rainfall, water discharge, and suspended-sediment discharge at Highland Creek above Highland Creek Dam gaging station $\mathbf{5}$

2. Water discharge and total sediment discharge at Highland Creek below Highland Creek Dam gaging station $\mathbf{5}$

3. Particle-size analyses for Highland Creek above Highland Creek Dam 6

4. Particle-size analyses for Highland Creek below Highland Creek Dam $\mathbf{8}$

5. Stage, area, and capacity data for December 1965 and April 1972 Highland Creek Reservoir surveys $\mathbf{1 0}$

6. Specific weight and particle-size analyses of Highland Creek Reservoir bed samples 11

7. Chemical analyses of Highland Creek Reservoir outflow 12

8. Summary of Highland Creek Reservoir sedimentation surveys 



\title{
Trap-Efficiency Study, Highland Creek Flood-Retarding Reservoir Near Kelseyville, California, Water Years 1966-77
}

\author{
By L. F. Trujillo
}

\begin{abstract}
This investigation is part of a nationwide study of trap efficiency of detention reservoirs. In this report, trap efficiency was computed from reservoir inflow and outflow sediment data and from reservoir survey and outflow data.

Highland Creek Reservoir is a flood-retarding reservoir located in Lake County, near Kelseyville, California. This reservoir has a maximum storage capacity of 3,199 acre-feet and permanent pool storage of 921 acre-feet. Mean annual rainfall for the 14.1 square-mile drainage area above Highland Creek Dam was 29 inches during the December 1965 to September 1977 study period. Resultant mean annual runoff was 17,100 acre-feet. Total reservoir inflow for the 11.8 year study period was 202,000 acre-feet, transporting an estimated 126,000 tons $(10,700$ tons per year) of suspended sediment. Total reservoir outflow for the same period was 188,700 acre-feet, including 15,230 tons $(1,290$ tons per year) of sediment. Estimated trap efficiency for the study period was 88 percent, based on estimated sediment inflow and measured sediment ouflow.

Reservoir surveys made in December 1965 and April 1972 revealed a storage capacity loss of 35.8 acre-feet during the 6.3 year period. Computed by using an estimated specific weight, this loss represents 54,600 tons of deposited sediment. Sediment outflow during the same period was 8,890 tons. Trap efficiency for the survey period was 86 percent.
\end{abstract}

\section{INTRODUCTION}

The U.S. Geological Survey, in cooperation with the U.S. Soil Conservation Service, began a sedimentation study of Highland Creek Reservoir near Kelseyville, Calif., in December 1965. This study was part of a nationwide program to investigate the trap efficiency of detention reservoirs.

The objectives of this study were (a) to determine the effectiveness for retaining sediment inflow of a typical flood retarding reservoir in a northern California environment, (b) to define streamflow and sedimentdischarge characteristics of the Highland Creek drainage basin, and (c) to provide planning data for the design of future detention reservoirs.

Records of water and sediment discharge were compiled by U.S. Geological Survey personnel in the Santa Rosa Field Office. Reservoir survey information, including storage capacity, specific weight, and particlesize data were furnished by the U.S. Department of Agriculture.

\section{CHARACTERISTICS OF THE DRAINAGE BASIN}

The Highland Creek drainage basin upstream from Highland Creek Dam comprises $14.1 \mathrm{mi}^{2}$ on the northeastern flank of the Mayacmas Mountains, which are part of the northern Coast Ranges of California (figs. 1 and 2). The basin is underlain mainly by the Franciscan Formation of Jurassic and Cretaceous age, which consists of graywacke with minor interbedding of shale and conglomerate. Approximately one third of the Franciscan Formation in the basin is intruded with serpentine and basalt, which are more resistant to erosion than the Franciscan rocks (McNitt, 1968). The terrain in the upper basin is characterized by steep mountain slopes that reach altitudes more than $3,000 \mathrm{ft}$. Gently rolling hills dominate the terrain adjacent to the reservoir.

The basin has a mediterranean climate with a mean annual rainfall of 29 inches (U.S. Department of Commerce, 1967-77). Vegetal cover of the upper basin is dense and consists predominantly of chaparral. Grasslands and oak trees dominate the lower parts of the basin. The lower basin is used largely for grazing livestock and for recreation (a golf course is located near the east bank 


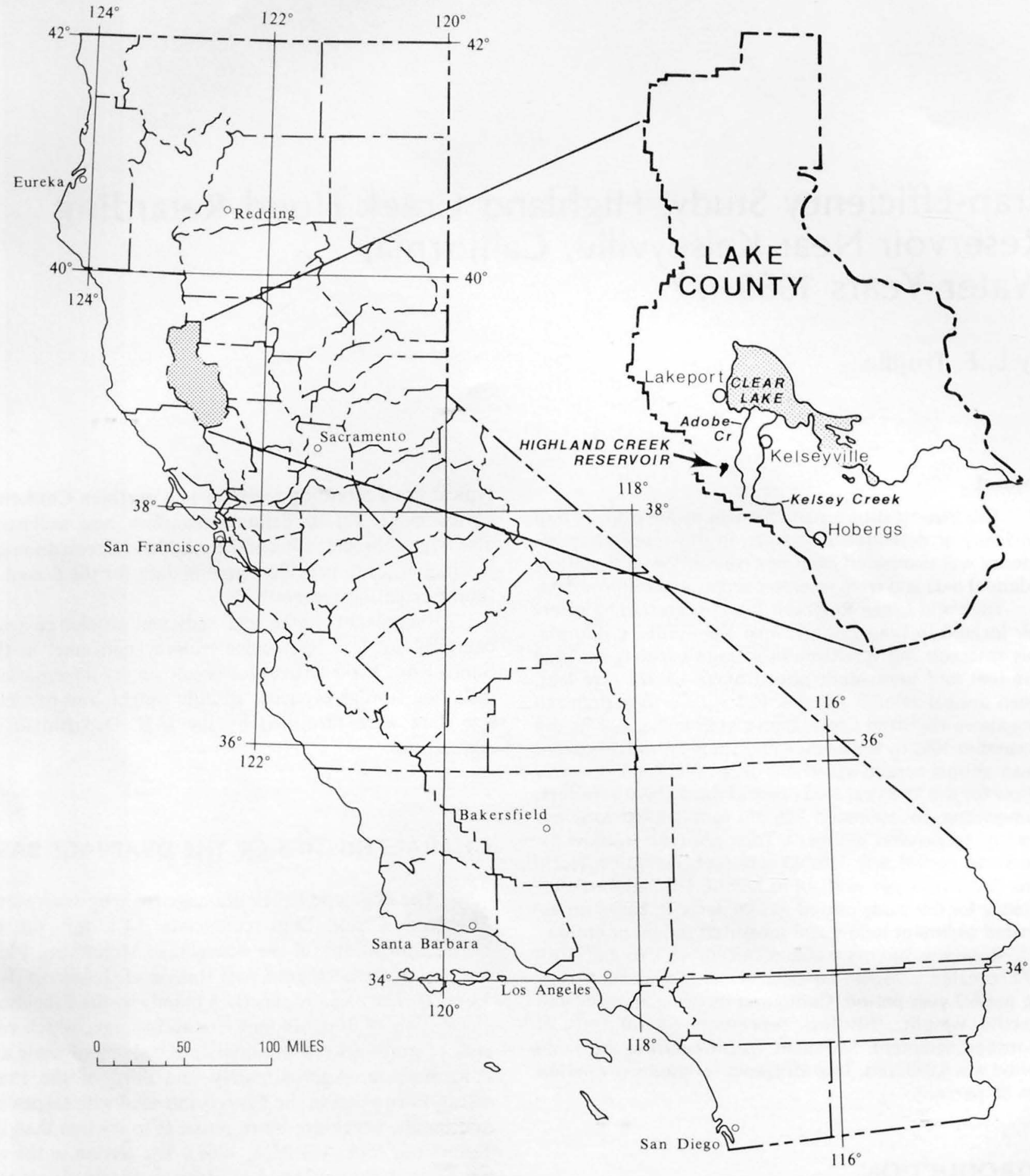

Figure 1. Index map.

of the reservoir). Fires have scarred sections of the basin in the recent past; their effects on basin runoff, however, are beyond the scope of this study.
The main stem of Highland Creek flows in a southeasterly direction for $2.8 \mathrm{mi}$ before turning northeastward and-flowing into Highland Creek Reser- 


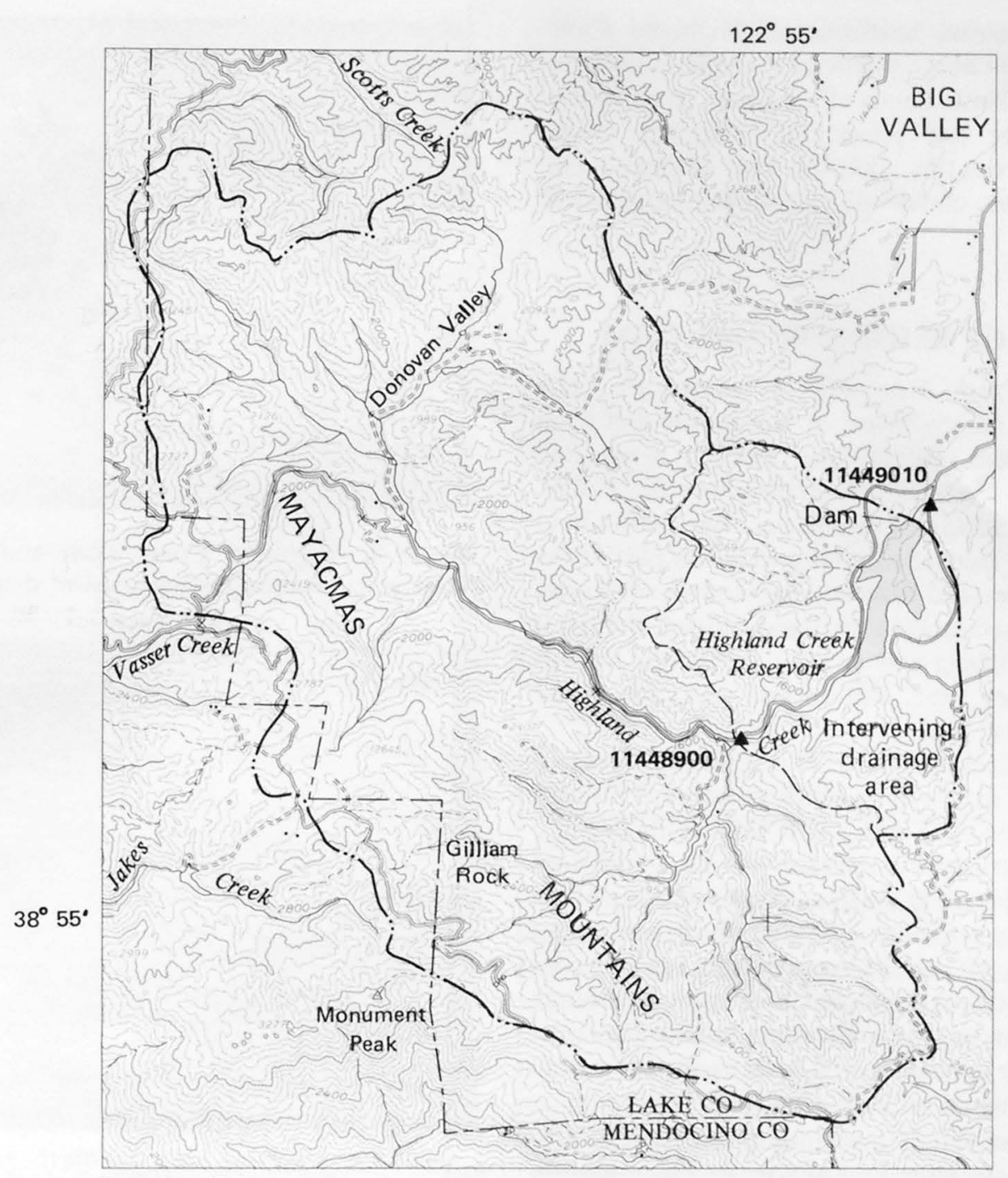

Base from U.S. Geological Survey

Kelseyville, Calif. 1:62,500, 1959

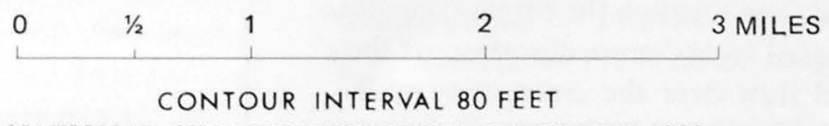

NATIONAL GEODETIC VERTICAL DATUM OF 1929

\section{EXPLANATION}

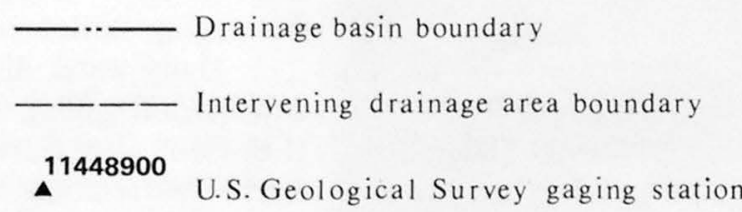

Figure 2. Location and features of Highland Creek Reservoir and drainage basin.

voir. Highland Creek and its major tributary converge approximately $1.7 \mathrm{mi}$ above Highland Creek Dam and drain $11.9 \mathrm{mi}^{2}$ of the basin. Runoff from the remaining
$2.2 \mathrm{mi}^{2}$ area above the dam is carried by a number of small streams that flow directly into the reservoir or is added directly to the reservoir as precipitation. 
The upper basin, northwest of Highland Creek Reservoir in and above Donovan Valley, contains numerous ponds. These ponds affect about 10 percent of the basin drainage and presumably trap any coarse material eroded from this area; the finer sediments (silt and clay), however, could still contribute to reservoir deposition.

\section{DESCRIPTION OF RESERVOIR AND DAM}

Highland Creek Reservoir is located in Lake County, Calif., $4 \mathrm{mi}$ southwest of Kelseyville and $6 \mathrm{mi}$ south of Clear Lake (fig. 1). The reservoir is oriented north-south in the Mayacmas foothills above Big Valley. At the principal spillway elevation, the reservoir is about a mile long and a quarter of a mile wide. As part of the Adobe Creek Watershed Project, Highland Creek Reservoir was constructed in 1961 for flood control, though it is also used for fishing and boating. Reservoir storage began in December 1961, and normal operation of the dam began in June 1962 .

Highland Creek Dam (fig. 3) is at the north end of the reservoir. The dam is an earthfill structure, $75 \mathrm{ft}$ high $(1,498 \mathrm{ft}$ crest elevation) and $250 \mathrm{ft}$ long at its crest.

The outlet structure in the reservoir is a 4 - by 8 -foot concrete tower adjacent to the dam (fig. 4). The top of the tower contains the principal spillway, which has a crest elevation of $1,462.5 \mathrm{ft}$. At the lower end the tower is connected to a 4-foot-square conduit that extends through the base of the dam to a concrete apron outside the reservoir. The reservoir maintains a 62.8 -acre permanent pool just below the principal spillway crest (1972 survey data).

Near the west end of the dam is an emergency spillway with a crest elevation of $1,485 \mathrm{ft}$. At this elevation the reservoir has a 137.8-acre surface area, and a discharge of $473 \mathrm{ft}^{3} / \mathrm{s}$ would flow through the principal spillway. At a water level equal to the crest elevation of the dam, $10,800 \mathrm{ft}^{3} / \mathrm{s}$ would flow over the emergency spillway and $520 \mathrm{ft}^{3} / \mathrm{s}$ would flow through the principal spillway (Hansen, 1960).

\section{METHOD OF INVESTIGATION}

\section{Runoff}

Surface-water inflow to Highland Creek Reservoir was monitored at gaging station 11448900 (Highland Creek above Highland Creek Dam), $1.7 \mathrm{mi}$ upstream from the dam (table 1, fig. 5). Operation of a continuousstage recorder began at this station in October 1962 and continued through the 1977 water year. A tipping-bucket rain gage was installed in November 1962. Rainfall data were collected until July 1967, when the rain gage was removed. Data in table 1 are only for the 11.8-year study period.

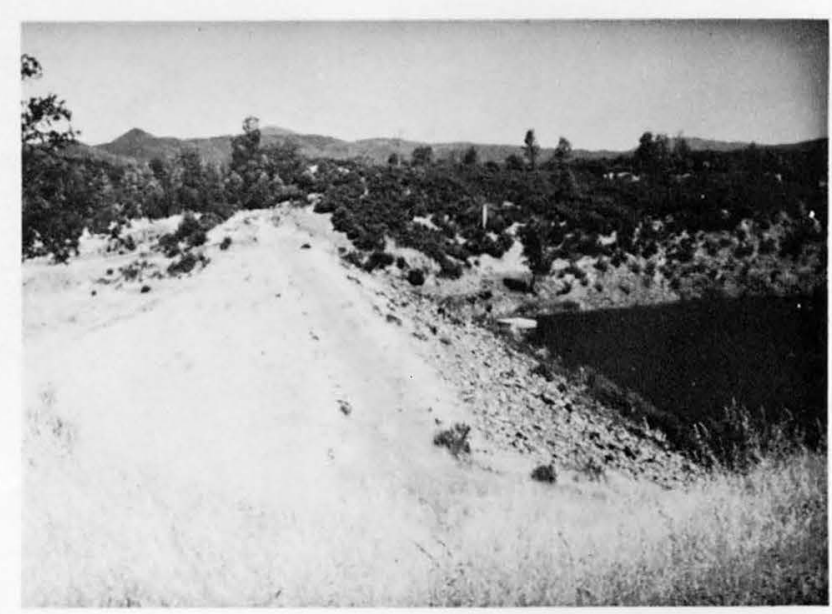

Figure 3. Highland Creek Dam and outlet structure. View is to southeast along crest of dam.

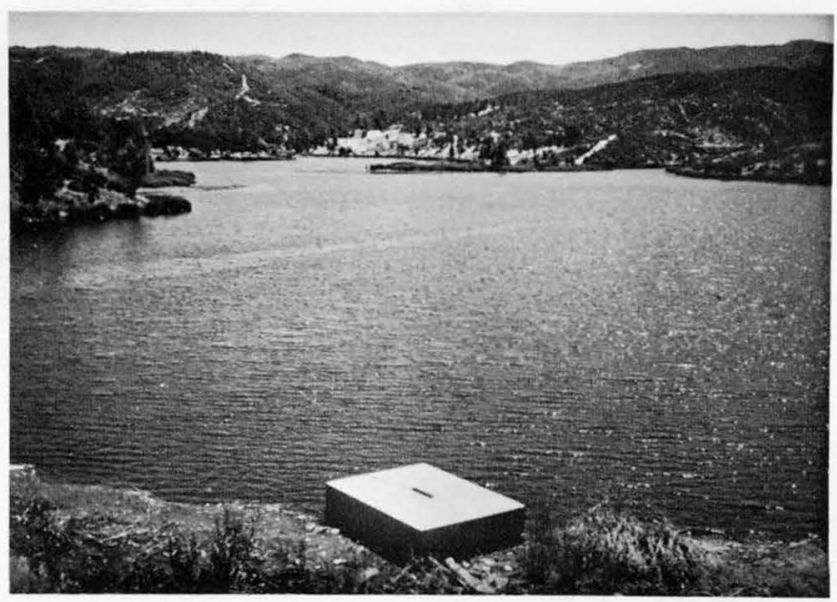

'Figure 4. Highland Creek Reservoir and principal outlet structure. View is upstream.

Surface-water outflow from Highland Creek Reservoir was monitored at gaging station 11449010 (Highland Creek below Highland Creek Dam), about $500 \mathrm{ft}$ downstream from the dam (table 2). The operation of a continuous-stage recorder began in December 1965 and continued through 1977 water year. All flow passing this gaging station is reservoir outflow.

Daily water discharge for both the upstream and downstream gaging stations was computed by standard U.S. Geological Survey methods for developing a stagedischarge-relation (rating curve) from streamflow measurements. The recorded stage data, with shiftingchannel corrections, were applied to the rating curve for discharge computations. These streamflow records were published by the U.S. Geological Survey (1963-70; 1971-74; 1975-77).

The 2.2-square-mile drainage area (15 percent of the basin) between the inflow gaging station and 
Table 1. Rainfall, water discharge, and suspended-sediment discharge at Highland Creek above Highland Creek Dam gaging station

\begin{tabular}{cccc}
\hline $\begin{array}{c}\text { Water } \\
\text { year }\end{array}$ & $\begin{array}{c}\text { Rainfall } \\
\text { (inches) }\end{array}$ & $\begin{array}{c}\text { Water } \\
\text { discharge } \\
\text { (acre-feet) }\end{array}$ & $\begin{array}{c}\text { Estimated suspended- } \\
\text { sediment discharge } \\
\text { (tons) }\end{array}$ \\
\hline $1966^{2}$ & 24.4 & 10,480 & 5,000 \\
1967 & 48.1 & 17,020 & 4,250 \\
1968 & 26.4 & 11,530 & 4,410 \\
1969 & 36.2 & 23,690 & 9,430 \\
1970 & 33.2 & 21,260 & 14,100 \\
1971 & 26.2 & 13,470 & 3,980 \\
1972 & 25.4 & 4,700 & 150 \\
1973 & 32.9 & 21,940 & 11,200 \\
1974 & 38.6 & 32,760 & 51,200 \\
1975 & 29.0 & 16,600 & 6,030 \\
1976 & 11.8 & 1,540 & 30 \\
1977 & 13.2 & 636 & 9 \\
\hline Total $^{3}$ & 345.4 & 175,600 & 109,800 \\
\hline Average $^{3}$ & 26 & 14,880 & 9,310 \\
\hline
\end{tabular}

${ }^{1}$ Rainfall data for the $1968-77$ water years estimated from Kelseyville and Lakeport rainfall data.

${ }^{2}$ December 1965 to September 1966.

${ }^{3}$ Rounded.

Highland Creek Dam was not monitored. To determine the total amount of runoff entering Highland Creek Reservoir, it was necessary to estimate the quantity of runoff contributed by the intervening area. The amount of runoff from any drainage area is dependent upon many factors, including quantity and distribution of rainfall, type and density of ground cover, soil type, and slope of the terrain. In-depth analysis of these and other factors is beyond the scope of this report. Rainfall intensity and runoff characteristics were assumed to be similar above and below the inflow gaging station. Total runoff into Highland Creek Reservoir was determined by adjusting the recorded runoff data by 15 percent to include the intervening drainage area.

\section{Suspended Sediment}

Suspended-sediment samples were collected at the upstream gaging station (11448900) during selected storm periods and at monthly intervals from December 1965 to January 1968. These periodic samples were depth-integrated, using either a U.S. D-49 or U.S. $\mathrm{DH}-48$ suspended-sediment sampler. Dip samples were taken when stream depths were less than $0.25 \mathrm{ft}$. A U.S. U-59 single-stage sampler attached to the stilling well was used to collect samples automatically at selected water levels.
Table 2. Water discharge and total sediment discharge at Highland Creek below Highland Creek Dam gaging station

\begin{tabular}{ccc}
\hline $\begin{array}{c}\text { Water } \\
\text { year }\end{array}$ & $\begin{array}{c}\text { Water } \\
\text { discharge } \\
\text { (acre-feet) }\end{array}$ & $\begin{array}{c}\text { Sediment } \\
\text { discharge } \\
\text { (tons) }\end{array}$ \\
\hline $1966^{1}$ & 10,320 & 1,100 \\
1967 & 20,230 & 1,600 \\
1968 & 11,600 & 908 \\
1969 & 26,440 & 1,730 \\
1970 & 25,480 & 2,660 \\
1971 & 16,160 & 798 \\
1972 & 5,070 & 95 \\
1973 & 21,150 & 2,370 \\
1974 & 33,250 & 2,670 \\
1975 & 17,640 & 1,280 \\
1976 & 1,200 & 20 \\
1977 & 194 & 1.4 \\
\hline Total $^{2}$ & 188,700 & 15,230 \\
\hline Average $^{2}$ & 15,990 & 1,290 \\
\hline
\end{tabular}

'Water-discharge records began in December 1965.
${ }^{2}$ Rounded.

Suspended-sediment samples of reservoir outflow were collected at the apron of the outlet tunnel of the dam (fig. 6). Depth-integrated samples were taken at regular intervals from December 1965 to September 1977, using a U.S. DH-48 sampler. Samples collected with a U.S. U-59 single-stage sampler, located in a road culvert $100 \mathrm{ft}$ downstream from the dam, aided in supplying peak concentration data.

All inflow and outflow samples were analyzed for suspended-sediment concentration. Selected samples were analyzed for particle-size distribution (tables 3 and 4). A number of the selected samples were split so that

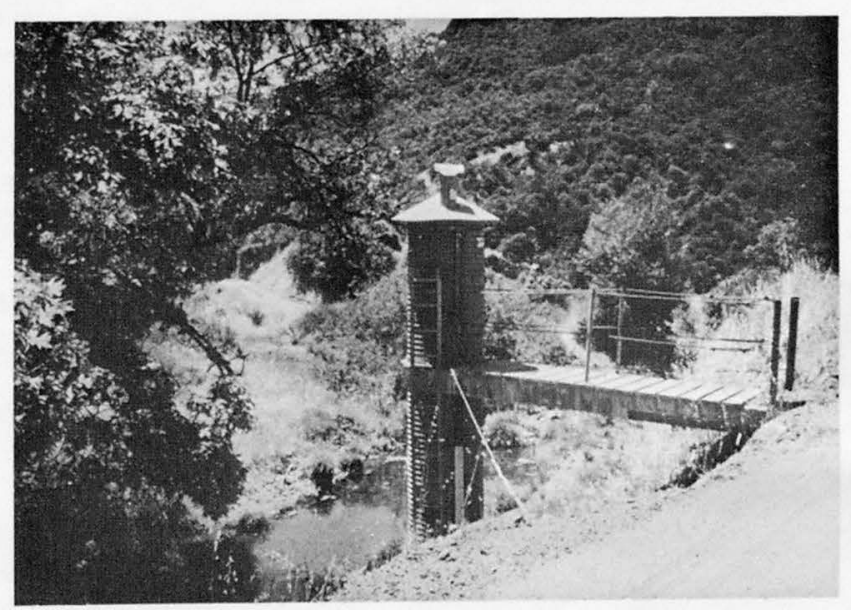

Figure 5. Gaging station on Highland Creek above Highland Creek Dam. 
Table 3. Particle-size analyses for Highland Creek above Highland Creek Dam

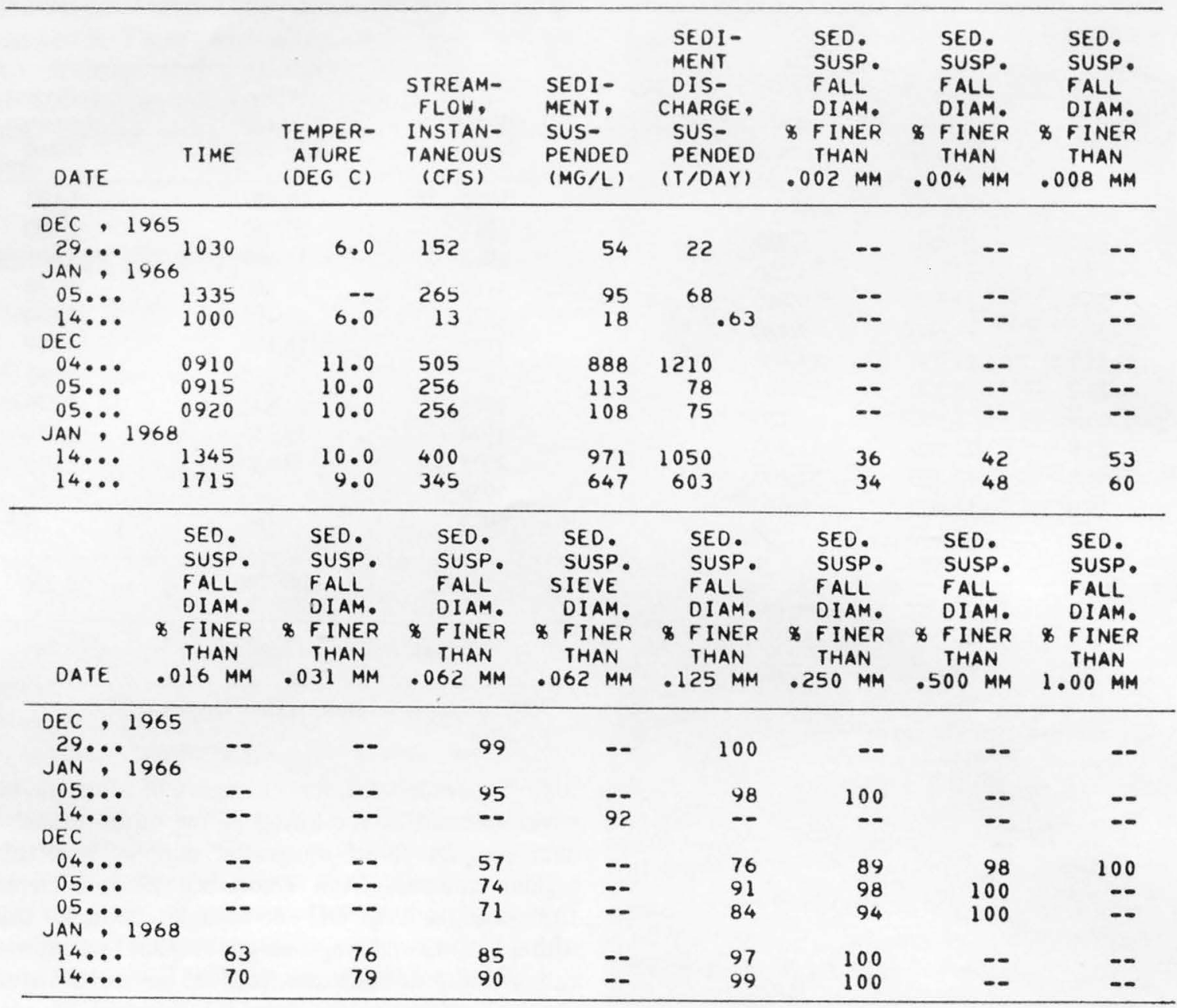

the same sample could be analyzed in both distilled- and native-water settling mediums. A significantly lower quantity of fine-particle sizes $(<0.062 \mathrm{~mm})$ indicated by a native-water analysis relative to a distilled-water (with a dispersing agent) analysis would suggest that some of

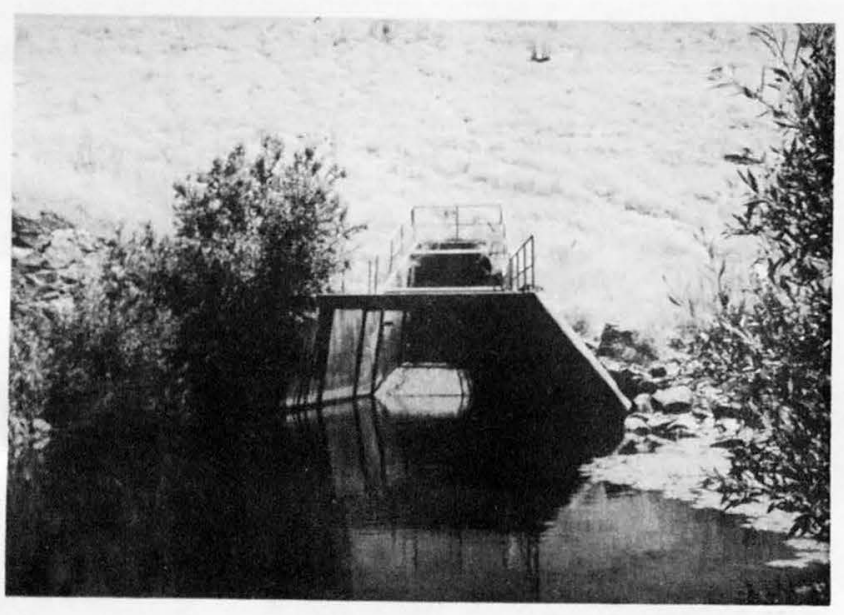

Figure 6. Outflow sampling site at outlet tunnel of Highland Creek Dam. these silt-clay particles are uniting, thereby forming larger particles (floccules) in native water. The amount of flocculation occurring in a reservoir frequently has a major effect on trap efficiency (Colby, 1963, p.34-35) because the fall velocities of the silt-clay particles increase when they unite; these united particles tend to settle to the reservoir bed instead of passing through the reservoir outlet. Two to four samples per year were analyzed for major dissolved ions to identify chemical constituents that may cause flocculation.

Annual suspended-sediment discharge at the upstream gaging station was computed by using the sediment-transport curve method. This method is based on developing a relation between water and suspendedsediment discharge from sediment-sample data and concurrent water-discharge data. Data collected during water years 1966-68 were used to develop an instantaneous sediment-transport curve (fig. 7). Two distinct transport curves were indicated from the sample data. Flows greater than $100 \mathrm{ft}^{3} / \mathrm{s}$ were the result of major storms. As water discharge $\left(Q_{w}\right)$ increased, suspendedsediment discharge $\left(Q_{S}\right)$ increased by an exponential rate of about 2.9 relative to water discharge $\left(Q_{\mathrm{S}}=1.02 \times 10^{-5}\right.$ 


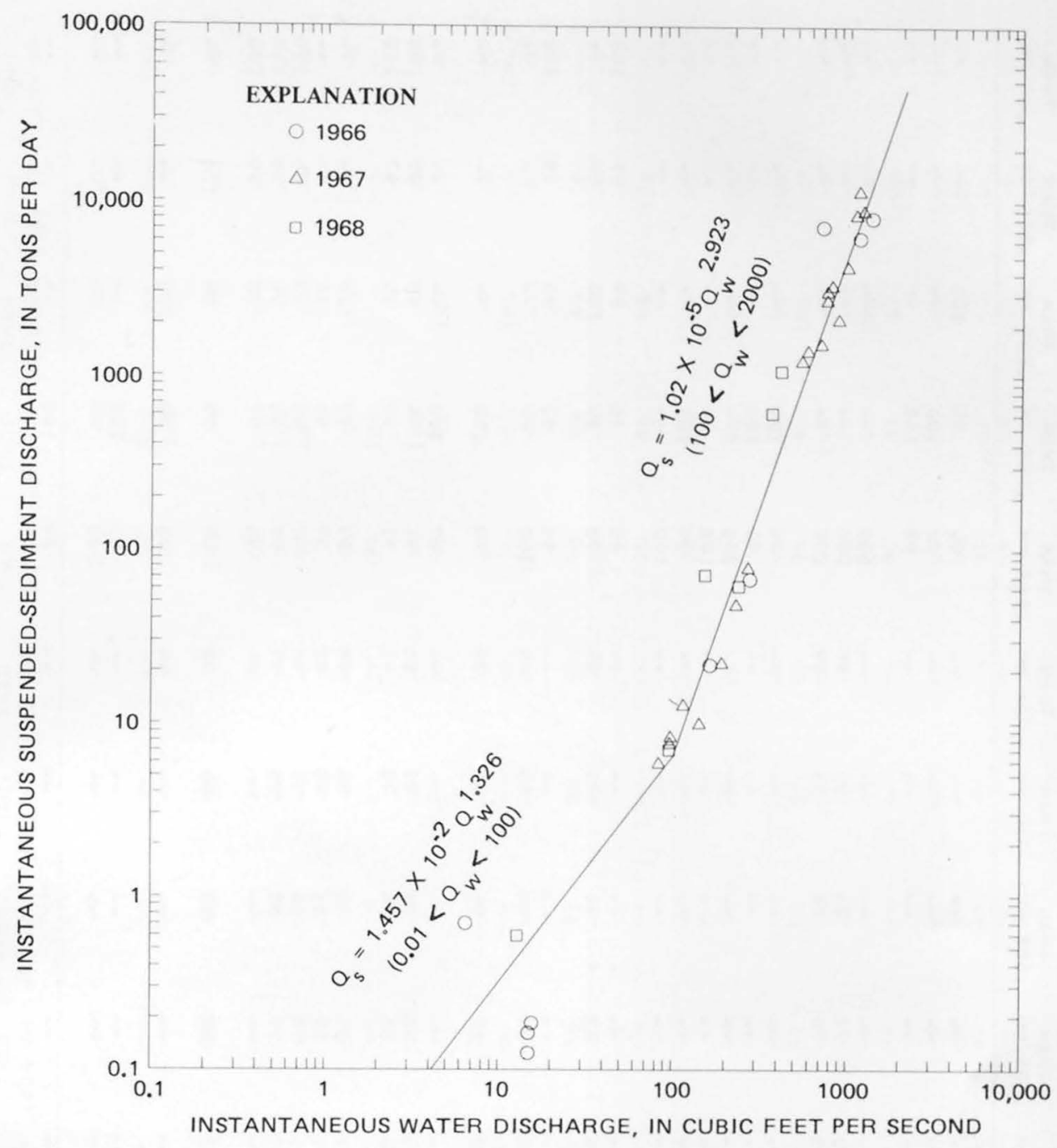

Figure 7. Relation between suspended-sediment discharge and water discharge, Highland Creek above Highland Creek Dam, 1966-68 water years.

$\mathrm{Q}_{\mathrm{w}}^{2.923}$ ). Flows less than $100 \mathrm{ft}^{3} / \mathrm{s}$ were generally the result of low-intensity storms or ground-water seepage. The relationship of suspended-sediment discharge to water discharge dropped to an exponential rate of about 1.3 for low flows $\left(\mathrm{Q}_{\mathrm{s}}=1.457 \times 10^{-2} \mathrm{Q}_{\mathrm{w}}^{1.2326}\right)$. Daily water-discharge data for water years $1966-77$ were applied to this curve to compute annual suspendedsediment discharges.

Total suspended-sediment discharge into Highland Creek Reservoir was determined by increasing the discharges computed from the transport curve by 15 percent to include sediment discharge from the 2.2-square-mile drainage area between the inflow gaging station and the dam.

Annual suspended-sediment discharge from the reservoir was determined from daily sediment records for the downstream gaging station. These records were computed by using concentration data from sediment samples with the water discharge record. Standard U.S.
Geological Survey techniques for computing daily suspended-sediment records were used. The turbulent flow conditions in the outlet tunnel caused all the released sediment to be in suspension. The published suspendedsediment discharge is, therefore, equivalent to total sediment discharge (table 2).

Sediment and chemical data for both the upstream and downstream gaging stations were published by the U.S. Geological Survey (1966-74; 1975-77).

\section{Reservoir Surveys}

In 1960 , prior to construction of the dam, a survey of the reservoir site indicated that the initial storage capacity of Highland Creek Reservoir would be 1,090 acre-ft at the principal spillway elevation and 3,500 acre-ft at the emergency spillway elevation.

The reservoir was resurveyed in December 1965 and April 1972 by the Agricultural Research Service 
Table 4. Particle-size analyses for Highland Creek below Highland Creek Dam

\begin{tabular}{|c|c|c|c|c|c|c|c|c|c|c|c|c|c|c|c|c|c|c|c|c|c|c|c|}
\hline \multirow[b]{2}{*}{ DATE } & \multirow[t]{2}{*}{ TIME } & \multirow{2}{*}{$\begin{array}{l}\text { TEMPER - } \\
\text { ATURE, } \\
\text { WATER } \\
\text { (DEG C) }\end{array}$} & \multirow[t]{2}{*}{$\begin{array}{l}\text { STREAM- } \\
\text { FLOW, } \\
\text { INSTAN- } \\
\text { TANEOUS } \\
\left(\mathrm{ft}^{3} / \mathrm{s}\right)\end{array}$} & \multirow[t]{2}{*}{$\begin{array}{l}\text { SEDI - } \\
\text { MENT, } \\
\text { SUS- } \\
\text { PENDED } \\
\text { (MG LL) }\end{array}$} & \multirow[t]{2}{*}{$\begin{array}{l}\text { SEDI- } \\
\text { MENT } \\
\text { DIS- } \\
\text { CHARGE, } \\
\text { SUS- } \\
\text { PENDED } \\
\text { (ton/d) }\end{array}$} & \multicolumn{2}{|c|}{$\begin{array}{l}\text { SED. } \\
\text { SUSP. } \\
\text { FALL } \\
\text { OIAM. } \\
\text { क FINER } \\
\text { THAN }\end{array}$} & \multicolumn{2}{|c|}{$\begin{array}{l}\text { SED. } \\
\text { SUSP. } \\
\text { FALL } \\
\text { DIAM. } \\
\text { OINER } \\
\text { THAN }\end{array}$} & \multicolumn{2}{|c|}{$\begin{array}{l}\text { SED. } \\
\text { SUSP. } \\
\text { FALL } \\
\text { OIAM. } \\
\text { * FINER } \\
\text { THAN }\end{array}$} & \multicolumn{2}{|c|}{$\begin{array}{l}\text { SED. } \\
\text { SUSP. } \\
\text { FALL } \\
\text { DIAM. } \\
\text { DIINER } \\
\text { THAN }\end{array}$} & \multicolumn{2}{|c|}{$\begin{array}{l}\text { SED. } \\
\text { SUSP. } \\
\text { FALL } \\
\text { DIAM. } \\
\text { \$ FINER } \\
\text { THAN }\end{array}$} & $\begin{array}{l}\text { SED. } \\
\text { SUSP. } \\
\text { SIEVE } \\
\text { DIAM. } \\
\text { \& FINER } \\
\text { THAN }\end{array}$ & \multirow[t]{2}{*}{$\begin{array}{l}\text { SED. } \\
\text { SUSP. } \\
\text { SIEVE } \\
\text { DIAM. } \\
\text { \& FINER } \\
\text { THAN } \\
\text { TH } 125 \text { MM }\end{array}$} & \multicolumn{2}{|c|}{$\begin{array}{l}\text { SED. } \\
\text { SUSP. } \\
\text { SIEVE } \\
\text { DIAM. } \\
\text { FIINER } \\
\text { THAN }\end{array}$} & \multicolumn{2}{|c|}{$\begin{array}{l}\text { SED. } \\
\text { SUSP. } \\
\text { SIEVE } \\
\text { DIAM. } \\
\text { FINER } \\
\text { THAN }\end{array}$} & \multicolumn{2}{|c|}{$\begin{array}{l}\text { SEO. } \\
\text { SUSP. } \\
\text { SIEVE } \\
\text { DIAM. } \\
\text { \& FINER } \\
\text { THAN }\end{array}$} \\
\hline & & & & & & & MM & .004 & MM & .008 & MM & .016 & MM & .031 & MM & $.062 \mathrm{MM}$ & & .250 & & .500 & MM & 1.00 & \\
\hline \multicolumn{2}{|c|}{ JAN , 1966} & & & & & & & & & & & & & & & & & & & & & & \\
\hline $06 \ldots$ & 1300 & 8.9 & 495 & 116 & 155 & & -- & & -- & & -- & & -- & & -- & 99 & 99 & & 100 & & -- & & -- \\
\hline $06 \ldots$ & 1530 & 8.9 & 485 & 108 & 141 & & -- & & -- & & -- & & -- & & -- & 96 & 100 & & - & & -- & & -- \\
\hline${ }_{D E C}^{31} \cdots$ & 0800 & 8.3 & 86 & 99 & 23 & & -- & & -- & & -- & & -- & & -- & 98 & 100 & & -- & & -- & & - \\
\hline $04 \ldots$ & 0930 & 10.6 & 299 & 99 & 80 & & -- & & -- & & -- & & -- & & -- & 100 & -- & & -- & & -- & & -- \\
\hline $05 \ldots$ & 0935 & 10.0 & 530 & 165 & 236 & & 70 & & 77 & & 84 & & 91 & & 96 & 100 & -- & & -- & & -- & & -- \\
\hline \multicolumn{2}{|c|}{ JAN , 1967} & 10.0 & 530 & 165 & 236 & & 53 & & 70 & & 88 & & 94 & & 99 & 100 & -- & & -- & & -- & & -- \\
\hline $21 \ldots$ & 1000 & 8.9 & 520 & 91 & 128 & & -- & & -- & & -- & & -- & & -- & 99 & 100 & & -- & & -- & & -. \\
\hline $21 \ldots$ & 1700 & 7.8 & 530 & 120 & 172 & & -- & & -- & & -- & & -- & & -- & 99 & 100 & & -- & & -- & & -- \\
\hline $24 \ldots$ & 0700 & -- & 106 & 96 & 27 & & -- & & -- & & -- & & - & & -- & 100 & -- & & -- & & -- & & -- \\
\hline $24 \ldots$ & 1130 & -- & 193 & 75 & 39 & & -- & & -- & & -- & & -- & & -- & 100 & -- & & -- & & $=$ & & -- \\
\hline $26 \ldots$ & 1000 & -- & 80 & 47 & 10 & & -- & & -- & & -- & & -- & & -- & 99 & 100 & & -- & & - & & -- \\
\hline \multirow{2}{*}{\multicolumn{2}{|c|}{ FEB 1968}} & -- & 110 & 50 & 15 & & -- & & -- & & -- & & -- & & -- & 100 & -- & & -- & & -- & & $\cdots$ \\
\hline & & 10.0 & 194 & 77 & 40 & & -- & & - & & -- & & -- & & -- & 65 & 76 & & 89 & & 97 & & 100 \\
\hline $07 \ldots$ & 1300 & 7.0 & 7.2 & 30 & .58 & & -- & & -- & & -- & & -- & & -- & 90 & 93 & & 96 & & 98 & & 100 \\
\hline$\underset{F E B}{17 \ldots}$ & 1210 & 8.0 & 34 & 66 & 6.1 & & 78 & & 97 & & 99 & & 99 & & 99 & 100 & -- & & -- & & - & & $=$ \\
\hline OEC & 1400 & 6.0 & 105 & 37 & 10 & & 70 & & 88 & & 96 & & 97 & & 98 & 99 & 100 & & -- & & -- & & -- \\
\hline $12 \ldots$ & 1630 & 11.0 & 237 & 41 & 26 & & -- & & -- & & -- & & -- & & -- & 97 & 100 & & -- & & -- & & -- \\
\hline $19 \ldots$ & 0900 & 11.0 & 634 & 26 & 45 & & 73 & & 80 & & 89 & & 90 & & 91 & 91 & 94 & & 95 & & 97 & & 100 \\
\hline $\begin{array}{c}19 \ldots \\
\text { JAN } \\
197\end{array}$ & $0^{0900}$ & 11.0 & 634 & 26 & 45 & & 30 & & 55 & & 84 & & 90 & & 91 & 91 & 94 & & 95 & & 97 & & 100 \\
\hline $15 \ldots$ & 1700 & 10.0 & 221 & 84 & 50 & & 64 & & 85 & & 92 & & 96 & & 98 & 99 & 99 & & 100 & & - & & -- \\
\hline $15 \ldots \mathrm{A}$ & 1700 & 10.0 & 221 & 84 & 50 & & 38 & & 59 & & 81 & & 95 & & 99 & 99 & 99 & & 100 & & -- & & -- \\
\hline $21 \ldots$ & 1100 & 11.0 & 580 & 66 & 105 & & 61 & & 78 & & 88 & & 95 & & 96 & 97 & 98 & & 98 & & 99 & & 100 \\
\hline $21 \ldots \mathrm{A}$ & 1100 & 11.0 & 588 & 66 & 105 & & 43 & & 58 & & 80 & & 95 & & 97 & 97 & 98 & & 98 & & 99 & & 100 \\
\hline $27 \ldots$ & 1230 & 10.0 & 273 & 129 & 95 & & -- & & -- & & -- & & -- & & -- & 96 & 97 & & 98 & & 99 & & 100 \\
\hline $28 \ldots$ & 0930 & 10.0 & 247 & 25 & 17 & & 73 & & 88 & & 93 & & 96 & & 98 & 99 & 99 & & 99 & & 100 & & -- \\
\hline JAN, 197 & & & & & & & & & & & & & & & & & & & & & & & \\
\hline${ }_{\text {MAR }}^{16} \cdots$ & 1130 & 7.0 & 494 & 34 & 45 & & -- & & -- & & -- & & -- & & -- & 98 & 99 & & 100 & & -- & & -- \\
\hline $12 \ldots$ & 1415 & 9.0 & 625 & 6 & 10 & & -- & & -- & & -- & & -- & & -- & 85 & 100 & & -- & & -- & & -- \\
\hline $16 \ldots$ & 1100 & 9.5 & 32 & 31 & 2.7 & & -- & & -- & & -- & & -- & & -- & 100 & -- & & -- & & -- & & -- \\
\hline $04 \ldots$ & 1400 & 17.5 & .59 & 36 & .06 & & -- & & -- & & -- & & -- & & -- & 89 & 100 & & -- & & -- & & -- \\
\hline
\end{tabular}


Table 4. Particle-size analyses for Highland Creek below Highland Creek Dam-Continued

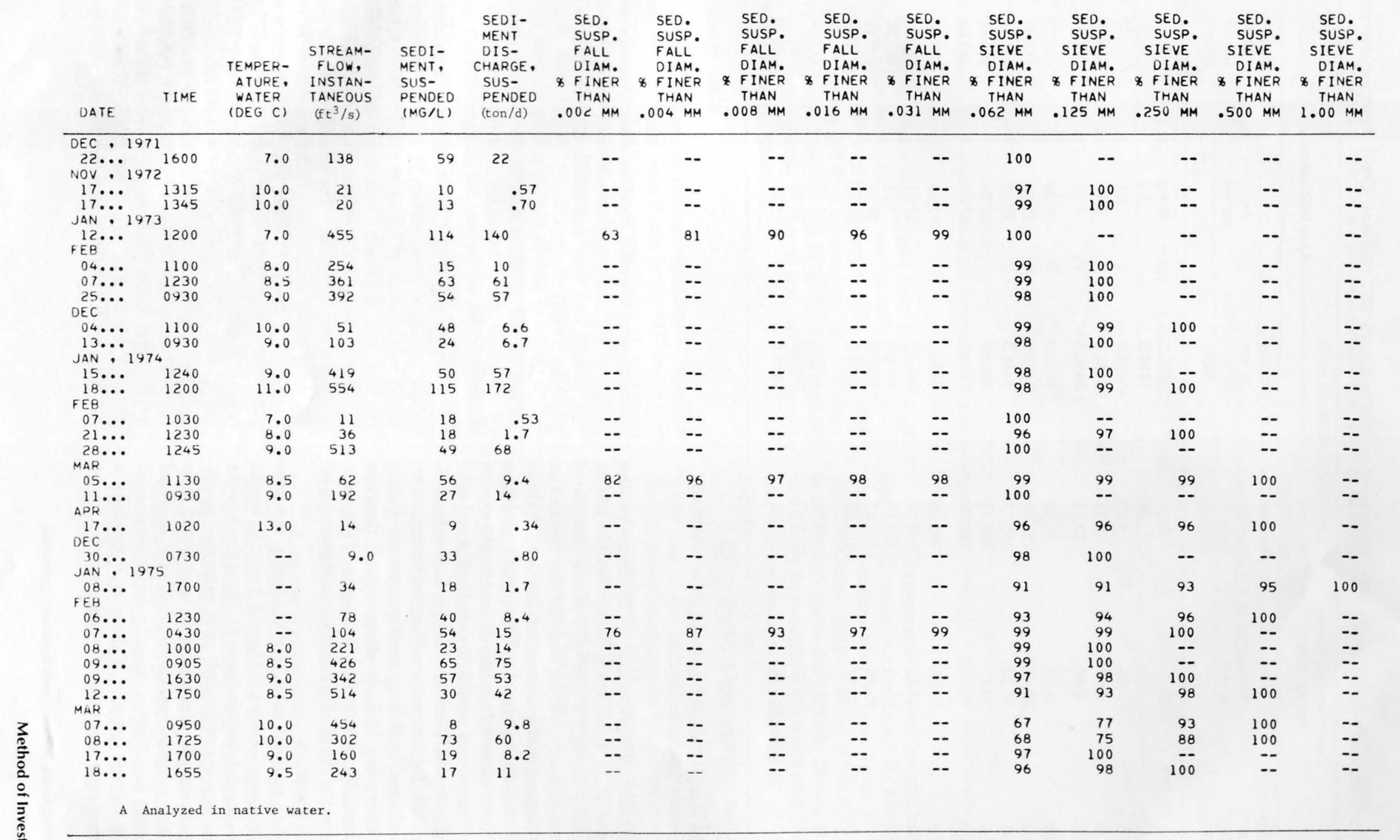


Table 5. Stage, area, and capacity data for December 1965 and April 1972 Highland Creek Reservoir surveys ${ }^{1}$

\begin{tabular}{|c|c|c|c|c|c|}
\hline \multicolumn{3}{|c|}{$\begin{array}{l}\text { December } 1965 \text { Survey } \\
\quad \text { (Revised 1972) }\end{array}$} & \multicolumn{3}{|c|}{ April 1972 survey } \\
\hline $\begin{array}{l}\text { Elevation } \\
\text { in feet } \\
\text { (NGVD of } \\
\text { 1929) }\end{array}$ & $\begin{array}{l}\text { Area } \\
\text { (acres) }\end{array}$ & $\begin{array}{l}\text { Accumu- } \\
\text { lative } \\
\text { capacity } \\
\text { (acre-ft) }\end{array}$ & $\begin{array}{l}\text { Elevation, } \\
\text { in feet } \\
\text { (NGVD of } \\
\text { 1929) }\end{array}$ & $\begin{array}{c}\text { Area } \\
\text { (acres) }\end{array}$ & $\begin{array}{c}\text { Accumu- } \\
\text { lative } \\
\text { capacity } \\
\text { (acre-ft) }\end{array}$ \\
\hline${ }^{2} 1424.7$ & 0 & 0 & ${ }^{2} 1425.2$ & 0 & 0 \\
\hline 1426.0 & .21 & .09 & 1426.0 & .13 & .03 \\
\hline 1428.0 & .71 & .97 & 1428.0 & .68 & .77 \\
\hline 1432.0 & 2.59 & 7.17 & 1432.0 & 2.46 & 6.69 \\
\hline 1436.0 & 8.68 & 28.53 & 1436.0 & 8.31 & 27.09 \\
\hline 1440.0 & 16.73 & 78.49 & 1440.0 & 16.49 & 75.77 \\
\hline 1444.0 & 23.04 & 157.69 & 1444.0 & 22.54 & 153.53 \\
\hline 1448.0 & 31.20 & 265.77 & 1448.0 & 30.10 & 258.45 \\
\hline 1452.0 & 39.97 & 407.73 & 1452.0 & 38.34 & 395.01 \\
\hline 1456.0 & 48.75 & 584.89 & 1456.0 & 47.84 & 567.01 \\
\hline 1460.0 & 57.36 & 796.89 & 1460.0 & 55.41 & 773.33 \\
\hline${ }^{3} 1462.5$ & 64.62 & 949.27 & ${ }^{3} 1462.5$ & 62.81 & 921.01 \\
\hline 1466.0 & 76.66 & 1196.19 & 1466.0 & 75.01 & 1161.88 \\
\hline 1470.0 & 89.65 & 1528.47 & 1470.0 & 89.33 & 1490.16 \\
\hline 1474.0 & 102.77 & 1913.03 & 1474.0 & 103.12 & 1874.72 \\
\hline 1478.0 & 115.34 & 2348.99 & 1478.0 & 115.62 & 2311.96 \\
\hline 1482.0 & 128.22 & 2835.87 & 1482.0 & 128.40 & 2799.76 \\
\hline${ }^{4} 1485.0$ & 137.70 & 3234.66 & 41485.0 & 137.76 & 3198.91 \\
\hline
\end{tabular}

'Table data from U.S. Department of Agriculture (1972).

${ }^{2}$ Low point in reservoir.

${ }^{3}$ Conservation pool-principal spillway elevation.

${ }^{4}$ Flood pool-emergency spillway elevation.

(U.S. Department of Agriculture, 1972). Range profiles were surveyed at 31 locations to determine the loss in storage capacity during the $1965-72$ period. Review of the stage-area-capacity data for both surveys revealed an apparent storage-capacity increase of 2.56 acre-ft above the $1,474 \mathrm{ft}$ elevation (table 5 ). This capacity increase may have been caused by channel and bank erosion above this elevation and possibly by sand and gravel mining as noted by the 1972 survey party (F. E. Dendy, U.S. Department of Agriculture, written communication, 1972). The channel and bank erosion occurred mostly below the emergency spillway elevation and therefore had little or no effect on the overall capacity of the reservoir. The extent of the mining activity is unknown and assumed to be minor.

Four bed-material samples taken below the principal spillway elevation were analyzed for specific weight and particle-size distribution (table 6). Breakdown of the bed-material sampler precluded more extensive sampling. Two grab samples were taken at unrecorded locations after the sampler breakdown and were analyzed only for particle size. The four specific-weight determinations did not include samples of the coarser deposits in the delta area and were therefore inadequate for an average specific-weight determination. Average specific weight of the total deposited sediment was estimated, using sample and field inspection data (Dendy, written commun., 1972).

\section{RESULTS OF INVESTIGATION}

\section{Runoff Data}

Annual runoff data for the drainage area above the inflow gaging station, shown in table 1, indicate that runoff was substantial for water years 1966-75. Most of the flow into Highland Creek Reservoir occurred from November through March each year; flow was minimal in August and September. The number of storms producing daily mean discharges greater than $50 \mathrm{ft}^{3} / \mathrm{s}$ ranged from zero in the 1977 water year to 15 or more in the 1970,1973 , and 1974 water years. Maximum instantaneous discharges of $2,980 \mathrm{ft}^{3} / \mathrm{s}$ on January 23,1970 , and $3,140 \mathrm{ft}^{3} / \mathrm{s}$ on January 16,1974 , were recorded at the upstream gaging station. Total recorded runoff for the 1965-77 study period was 175,000 acre-ft $(14,880$ acre$\mathrm{ft} / \mathrm{yr}$ ). Total inflow (including that from the intervening drainage area) into Highland Creek Reservoir was 202,000 acre-ft $(17,100$ acre-ft/yr $)$ for the study period. 
Table 6. Specific weight and particle-size analyses of Highland Creek Reservoir bed samples

[Date of collection, April 1972]

Particle size

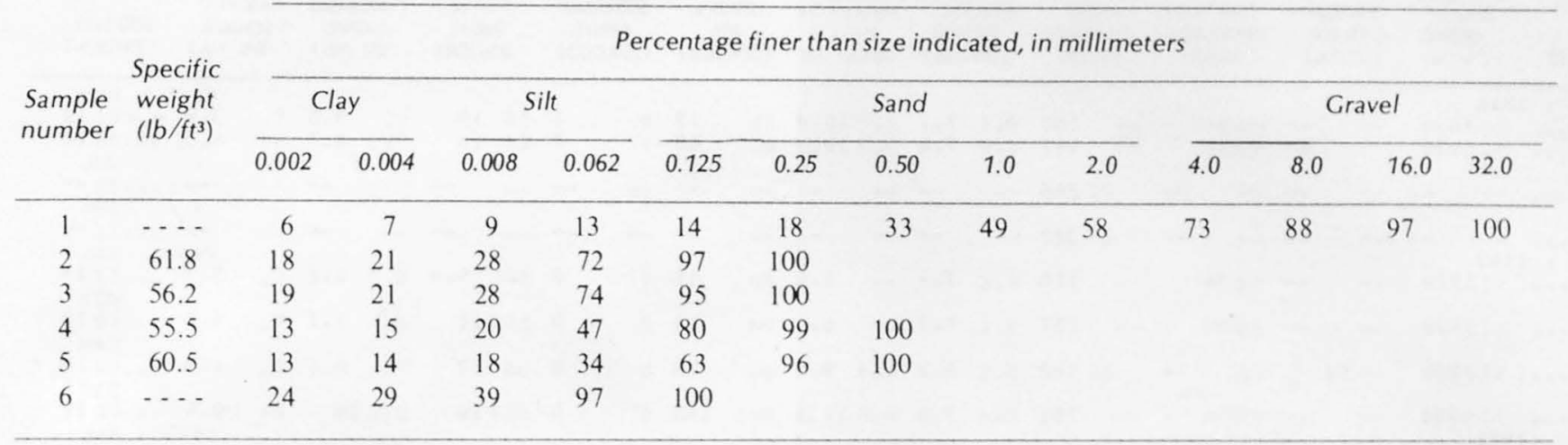

Note: Samples 2-5 at locations below the principal spillway elevation; samples 1 and 6 taken at unknown locations.

Reservoir release flow ranged from many days of no flow in each water year to a maximum instantaneous discharge of $765 \mathrm{ft}^{3} / \mathrm{s}$ on December 3, 1970. Daily mean outflows exceeding $475 \mathrm{ft}^{3} / \mathrm{s}$ occurred one or more times during water years $1966-71$ and 1973-75. Total outflow for the 11.8-year period of record was 188,700 acre-ft $(15,990$ acre-ft $/ \mathrm{yr})$ (table 2$)$.

\section{Sediment Data}

Annual suspended-sediment discharge at the inflow gaging station ranged from 9 tons in the 1977 water year to 51,200 tons in the 1974 water year (table 1). Maximum daily sediment discharge for the 11.8-year study period was 26,400 tons on January 16, 1974. Approximately 109,800 tons $(9,310$ ton/yr) of suspended sediment moved past the gaging station during the study period. Total suspended-sediment inflow (including the intervening drainage area) into Highland Creek Reservoir was about 126,000 tons $(10,700$ ton/yr) for the study period.

Data generated from the sediment transport curve were compared with the 1965 and 1972 reservoir survey data for verification. The sediment outflow was subtracted from the computed suspended sediment entering the reservoir during the survey period. The difference was compared with the sediment deposition calculated from the two surveys. The survey data indicated that 29 percent more sediment was deposited in the reservoir than was indicated by the transport curve data. Some of this difference is due to unmeasured bedload entering the reservoir during high flows. In addition, the sediment transport curve may not adequately represent the 6.3year survey period-the transport curve was developed from 3 years (1966-68 water years) of sampling data. Suspended-sediment discharge values at the inflow gaging station and into the reservoir are therefore considered estimated data.
Eight suspended-sediment samples taken at the inflow gaging station were analyzed for particle size. Sample concentrations ranged from 18 to $971 \mathrm{mg} / \mathrm{L}$, and water discharge ranged from 13 to $505 \mathrm{ft}^{3} / \mathrm{s}$. As indicated in table 3 , all suspended particles flowing into the reservoir during flows of $500 \mathrm{ft}^{3} / \mathrm{s}$ or less were finer than 1.000 $\mathrm{mm}$ and consisted predominantly of silt and clay-size particles $(<0.062 \mathrm{~mm})$.

Annual sediment outflow from Highland Creek Reservoir ranged from 1.4 tons in the 1977 water year to 2,670 tons in the 1974 water year (table 2). Maximum daily sediment discharge for the period of record was 390 tons on January 18, 1973. Total sediment released during the 11.8-year data period was 15,230 tons ( 1,290 ton/yr). The quantity of sediment released between the 1965 and 1972 surveys was 8,890 tons.

Fifty-nine outflow samples were analyzed for particle size. These samples ranged in sediment concentration from 6 to $165 \mathrm{mg} / \mathrm{L}$ and represented water discharge that ranged from 0.59 to $634 \mathrm{ft}^{3} / \mathrm{s}$. Results, shown in table 4 , indicate that approximately 96 percent of the sediment released from the reservoir consisted of silt and clay-size particles. During brief periods of heavy and prolonged storm activity, as much as 33 percent of the sediment passing through the outflow structure consisted of sandsize particles $(>0.062 \mathrm{~mm})$.

Analyses of outflow samples, both in native water and in distilled water with a dispersing agent, revealed that flocculation occurred in the native-water samples. The native-water samples had an average of 26 percent fewer clay-size particles $(0.002 \mathrm{~mm})$ than the same samples analyzed in the distilled-water medium. A high calcium-sodium ratio in water will cause flocculation of soil colloids (Rainwater and Thatcher, 1960, p. 127, 265). The high calcium-sodium ratio (3:1) indicated by the chemical analyses in table 7 and the significantly lower 
Table 7. Chemical analyses of Highland Creek Reservoir outflow

\begin{tabular}{|c|c|c|c|c|c|c|c|c|c|c|c|c|}
\hline DATE & TIME & $\begin{array}{l}\text { STREAM- } \\
\text { FLOW } \\
\text { (CFS) }\end{array}$ & $\begin{array}{l}\text { STREAM- } \\
\text { FLOW, } \\
\text { INSTAN- } \\
\text { TANEOUS } \\
\text { (CFS) }\end{array}$ & $\begin{array}{l}\text { SPE- } \\
\text { CIFIC } \\
\text { CON- } \\
\text { DUCT- } \\
\text { ANCE } \\
\text { (MICRO- } \\
\text { MHOS) }\end{array}$ & $\begin{array}{c}\text { PH } \\
\text { FIELLO } \\
\text { (UNITS) }\end{array}$ & $\begin{array}{l}\text { TEMPER- } \\
\text { ATURE, } \\
\text { WATER } \\
\text { (DEG C) }\end{array}$ & $\begin{array}{l}\text { HARD- } \\
\text { NESS } \\
\text { (MG/L } \\
\text { AS } \\
\text { CACO3) }\end{array}$ & $\begin{array}{l}\text { HARD- } \\
\text { NESS, } \\
\text { NONCAR- } \\
\text { BONATE } \\
\text { (MG/L } \\
\text { CACO3) }\end{array}$ & $\begin{array}{l}\text { CALCIUM } \\
\text { DIS- } \\
\text { SOLVEO } \\
\text { (MG L } \\
\text { AS CA) }\end{array}$ & $\begin{array}{l}\text { MAGNE- } \\
\text { SIUM, } \\
\text { DIS- } \\
\text { SOLVED } \\
\text { (MG/L } \\
\text { AS MG) }\end{array}$ & $\begin{array}{l}\text { SODIUM, } \\
\text { DIS- } \\
\text { SOLVED } \\
\text { (MGLL } \\
\text { AS NA) }\end{array}$ & $\begin{array}{l}\text { SODIUM } \\
\text { PERCENT }\end{array}$ \\
\hline $\begin{array}{l}\text { FEB } .1968 \\
19 . \ldots \\
20 \ldots\end{array}$ & $\begin{array}{l}8 \\
1630 \\
0930\end{array}$ & $\overline{-}$ & $\begin{array}{l}194 \\
236\end{array}$ & $\begin{array}{l}160 \\
147\end{array}$ & $\begin{array}{l}7.7 \\
7.6\end{array}$ & $\begin{array}{l}10.0 \\
10.0\end{array}$ & $\begin{array}{l}72 \\
68\end{array}$ & $\begin{array}{l}1 \\
0\end{array}$ & $\begin{array}{l}13 \\
13\end{array}$ & $\begin{array}{l}9.5 \\
8.7\end{array}$ & $\begin{array}{l}3.9 \\
4.3\end{array}$ & $\begin{array}{l}10 \\
12\end{array}$ \\
\hline $\begin{array}{l}\text { JUL } \\
01 \ldots \\
\text { AUG }\end{array}$ & -- & -- & -- & 265 & -- & -- & -- & -- & - & -- & -- & - \\
\hline JAN 11969 & 9 & -- & -- & 320 & -- & -- & -- & - & -- & -- & - & - \\
\hline FEB & 1210 & -- & 34 & 106 & 7.4 & 8.0 & 49 & 0 & 9.4 & 6.2 & 3.7 & 14 \\
\hline$\underset{\text { MAR }}{07} \cdots$ & 1400 & -- & 105 & 127 & 7.7 & 6.0 & 59 & 0 & 11 & 7.7 & 4.0 & 13 \\
\hline OEC & 1200 & 52 & -- & 142 & 8.2 & 9.0 & 63 & 0 & 12 & 8.0 & 4.6 & 14 \\
\hline JAN 1970 & $0^{0900}$ & -- & 634 & 301 & 7.8 & 11.0 & 143 & 0 & 26 & 19 & 8.8 & 12 \\
\hline $\begin{array}{l}21 \ldots \\
22 \ldots \\
\text { NOV }\end{array}$ & $\begin{array}{l}1100 \\
1700\end{array}$ & $538^{--}$ & 588 & $\begin{array}{r}111 \\
96\end{array}$ & $\begin{array}{l}8.1 \\
7.3\end{array}$ & $\begin{array}{l}11.0 \\
10.0\end{array}$ & $\begin{array}{l}52 \\
42\end{array}$ & $\begin{array}{l}1 \\
2\end{array}$ & $\begin{array}{l}10 \\
8.0\end{array}$ & $\begin{array}{l}6.4 \\
5.4\end{array}$ & $\begin{array}{l}3.8 \\
3.5\end{array}$ & $\begin{array}{l}14 \\
15\end{array}$ \\
\hline${ }_{\text {JAN }}^{28} \cdot 1971$ & $1^{0930}$ & -- & 247 & 428 & 7.5 & 10.0 & 196 & 0 & 34 & 27 & 13 & 13 \\
\hline $\begin{array}{l}16 \ldots \\
\operatorname{MAY}\end{array}$ & 1130 & -- & 494 & 126 & 7.1 & 7.0 & -- & 0 & 9.7 & 7.4 & 3.9 & 13 \\
\hline NOV & 1100 & .33 & $-\infty$ & 273 & 7.1 & 17.5 & 130 & 0 & 24 & 17 & 8.7 & 13 \\
\hline${ }_{\mathrm{DEC}}^{09} \cdots$ & 1045 & -- & .48 & 486 & 6.6 & 10.5 & 240 & 0 & 45 & 30 & 15 & 12 \\
\hline${ }_{\text {JAN }}^{02}, 1972$ & $2^{1300}$ & -- & .28 & 482 & 7.7 & 9.0 & 240 & 0 & 44 & 32 & 15 & 12 \\
\hline FEB & 1445 & -- & 8.9 & 279 & 7.7 & 5.5 & 130 & 0 & 24 & 17 & 7.9 & 12 \\
\hline NOV 04 & 1100 & -- & 20 & 270 & 7.5 & 5.0 & 140 & 0 & 25 & 18 & 8.4 & 12 \\
\hline DEC $\cdots$ & 1400 & -- & 20 & 323 & 7.0 & 10.0 & 150 & 0 & 27 & 20 & 10 & 13 \\
\hline JAH $\because 1973$ & $3^{0955}$ & -- & 5.8 & 307 & 7.2 & 7.0 & 150 & 0 & 27 & 19 & 9.9 & 13 \\
\hline${ }_{\text {MAR }} 12 \ldots$ & 0900 & -- & 459 & 97 & 7.6 & 7.0 & 53 & 3 & 10 & 6.7 & 3.2 & 12 \\
\hline${ }_{D E C}^{15} \cdots$ & 1055 & -- & 27 & 195 & 7.6 & 10.5 & 99 & 1 & 20 & 12 & 5.2 & 10 \\
\hline JAN $\because 1974$ & 1215 & -- & 51 & 89 & 7.3 & 9.0 & 43 & 0 & 8.7 & 5.1 & 2.3 & 10 \\
\hline $\begin{array}{l}15 \ldots \\
31 \ldots \\
\text { NOV }\end{array}$ & $\begin{array}{l}1240 \\
1330\end{array}$ & $=$ & $\begin{array}{r}419 \\
18\end{array}$ & $\begin{array}{l}116 \\
175\end{array}$ & $\begin{array}{l}7.6 \\
7.7\end{array}$ & $\begin{array}{l}9.0 \\
8.0\end{array}$ & $\begin{array}{l}56 \\
86\end{array}$ & $\begin{array}{l}2 \\
1\end{array}$ & $\begin{array}{l}12 \\
18\end{array}$ & $10^{6.4}$ & $\begin{array}{l}3.9 \\
5.3\end{array}$ & $\begin{array}{l}13 \\
12\end{array}$ \\
\hline $13 \ldots$ & 1115 & -- & .36 & 479 & 7.8 & 14.0 & 240 & 0 & 45 & 30 & 12 & 10 \\
\hline JAN 1975 & $5^{1638}$ & -- & 1.1 & 465 & 7.9 & 9.5 & 230 & 0 & 43 & 29 & 13 & 11 \\
\hline FEB $21 \ldots$ & 1450 & -- & 2.0 & 376 & 7.7 & 10.0 & 190 & 0 & 37 & 23 & 11 & 11 \\
\hline NOV & 1600 & -- & 101 & 151 & 7.4 & 5.5 & 70 & 0 & 14 & 8.6 & 4.6 & 12 \\
\hline${ }_{D E C}^{11} \cdots$ & 1130 & -- & .46 & -- & - & 12.0 & 210 & 0 & 40 & 27 & 12 & 11 \\
\hline JAN 1976 & $6^{1640}$ & -- & .79 & -- & -- & 11.5 & 210 & 0 & 39 & 27 & 13 & 12 \\
\hline FEB & 1225 & -- & .53 & -- & -- & 7.5 & 220 & 2 & 42 & 28 & 13 & 11 \\
\hline FEB $\because 1977$ & $7^{1530}$ & -- & 1.3 & -- & - & 7.0 & 240 & 0 & 46 & 31 & 15 & 12 \\
\hline $24 \ldots$ & 1420 & -- & 3.0 & -- & -- & 10.0 & 290 & 0 & 51 & 39 & 20 & 13 \\
\hline
\end{tabular}

percentage of clay-size particles in the native-water than in the distilled-water size analyses suggest that flocculation occurred in Highland Creek Reservoir. The extent of flocculation and its effect on the reservoir trap efficiency, however, could not be determined because of insufficient data.

\section{Reservoir Survey Data}

Results from the initial reservoir survey and the two succeeding surveys are shown in table 8 . At the emergency spillway elevation $(1,485.0 \mathrm{ft})$, the storage capacity of the reservoir was 3,500 acre-ft in December 
Table 7. Chemical analyses of Highland Creek Reservoir outflow-Continued

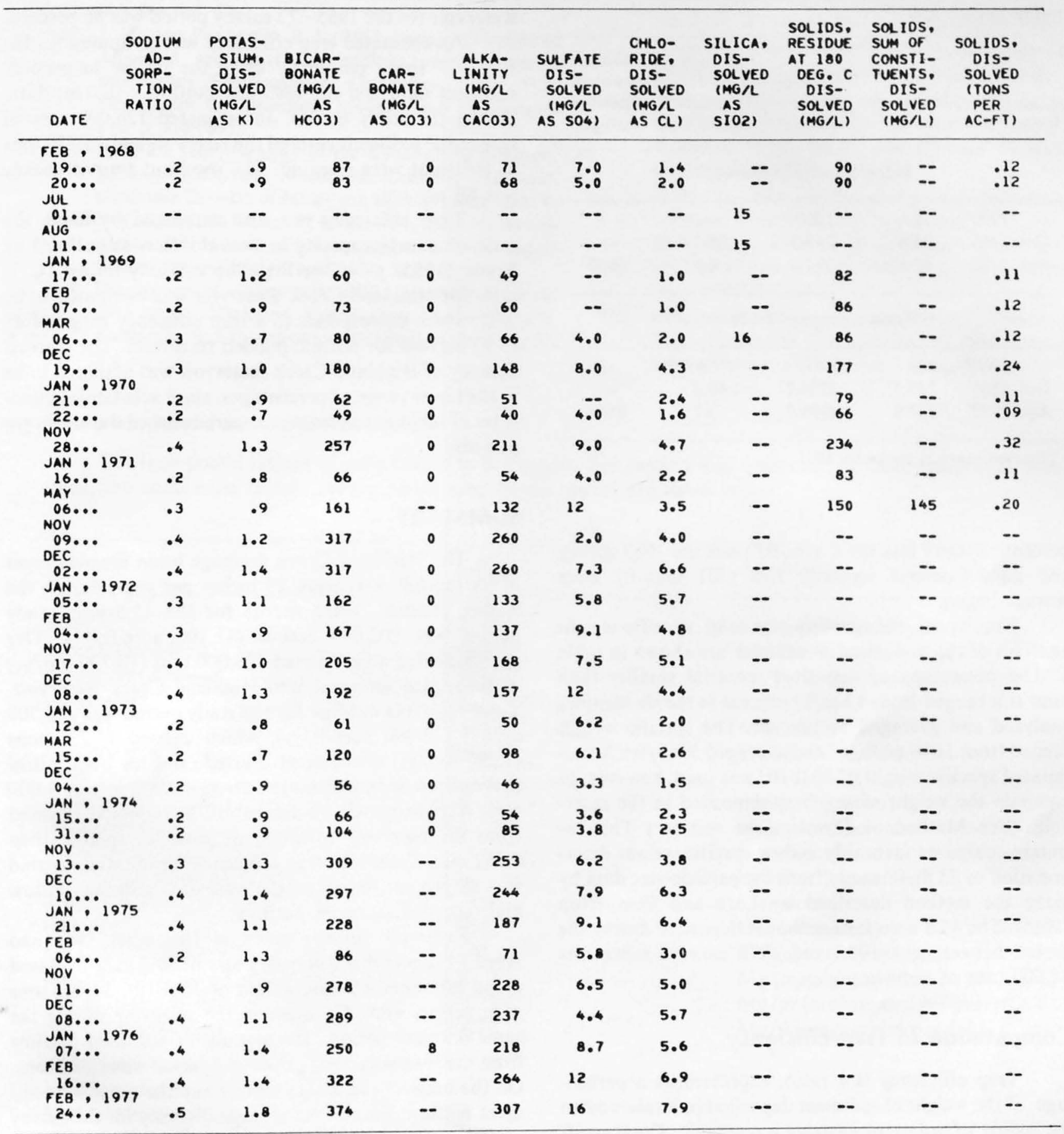

1961 and 3,234.7 acre-ft by December 1965. This 265acre-foot decrease represents a 7.6-percent loss in capacity in 4.0 years. Large storms in December 1964 and January 1965 probably were the cause of this sizable decrease in capacity. The 3,198.9-acre-foot storage capacity indicated by the 1972 survey revealed a 1.0- 
Table 8. Summary of Highland Creek Reservoir sedimentation surveys

\begin{tabular}{|c|c|c|c|c|}
\hline Survey date & $\begin{array}{c}\text { Surface area } \\
\text { (acres) }\end{array}$ & $\begin{array}{l}\text { Storage } \\
\text { capacity } \\
\text { (acre-ft) }\end{array}$ & $\begin{array}{c}\text { Annual } \\
\text { loss in storage } \\
\text { capacity } \\
\text { (acre-ft/yr) }\end{array}$ & $\begin{array}{c}\text { Annual } \\
\text { e sediment } \\
\text { deposition } \\
\text { (ton/yr) }\end{array}$ \\
\hline
\end{tabular}

Below principal spillway

\begin{tabular}{rllcc}
$1960^{1}$ & 72 & 1090 & -- & -- \\
Dec. 1965 & 64.6 & 949.3 & 35.2 & -- \\
Apr. 1972 & 62.8 & 921.0 & 4.5 & 6860 \\
\hline
\end{tabular}

Below emergency spillway

\begin{tabular}{rllrc}
$1960^{1}$ & 146 & 3500 & -- & -- \\
Dec. 1965 & 137.7 & 3234.7 & 66.3 & -- \\
Apr. 1972 & 137.8 & 3198.9 & 5.7 & 8660 \\
\hline
\end{tabular}

'Storage began in December 1961.

percent capacity loss ( 35.8 acre-ft) since the 1965 survey and an 8.6-percent capacity loss (301 acre-ft) since storage began.

Results of the particle-size and specific-weight analyses of the bed-material samples are shown in table 6. The percentage of deposited material smaller than sand size ranged from 13 to 97 percent in the six samples analyzed and averaged 56 percent. The specific weight ranged from 56 to $62 \mathrm{lb} / \mathrm{ft}^{3}$ and averaged $59 \mathrm{lb} / \mathrm{ft}^{3}$. An estimated specific weight of $70 \mathrm{lb} / \mathrm{ft}^{3}$ was used, however, to compute the weight of sediment deposited in the reservoir. (See Method of Investigation section.) This estimate compares favorably with a specific-weight determination of $73 \mathrm{lb} / \mathrm{ft}^{3}$ made from the particle-size data by using the method described by Lara and Pemberton (1965). The 35.8 acre-ft of sediment deposited during the period between the 1965 and 1972 surveys represents 54,600 tons of sediment.

\section{Computation of Trap Efficiency}

Trap efficiency is a ratio, expressed as a percentage, of the weight of sediment deposited in a reservoir to the weight of sediment entering a reservoir. The trap efficiency of Highland Creek Reservoir was computed by using data from the December 1965 and April 1972 reservoir surveys, together with the sediment-outflow data. The surveys indicated a sediment deposition of 35.8 acre$\mathrm{ft}$ during the 6.3-year period. Using an estimated specific weight of $70 \mathrm{lb} / \mathrm{ft}^{3}$ to convert from volume to weight, 54,600 tons of sediment were deposited in the reservoir. A total of 8,890 tons of sediment was discharged from the reservoir during the same period. The total weight of sediment entering the reservoir was therefore 63,490 tons. The resultant trap efficiency of Highland Creek Reservoir for the $1965-72$ survey period was 86 percent.

An estimated trap efficiency was computed for the 1965-77 study period by using the inflow suspendedsediment data and the recorded outflow sediment data. During the study period, an estimated 126,000 tons of suspended sediment entered the reservoir and 15,230 tons of sediment were released. The resultant trap efficiency was 88 percent.

Trap efficiency was also estimated by using the ratio of storage capacity to annual inflow as outlined by Brune (1953, p. 407-418). The capacity-inflow (C/I) ratio for Highland Creek Reservoir was computed to be 0.22 , which corresponds to a trap efficiency range of 87 to 97 percent for normal ponded reservoirs. The trap efficiency of Highland Creek Reservoir was assumed to be in the lower range of percentages, since substantial quantities of sediment-laden water were released during storm periods.

\section{SUMMARY}

The Highland Creek drainage basin receives most of its rainfall, averaging 29 inches per year, during the winter months. Total runoff for the 11.8-year study period was 202,000 acre-ft $(17,100$ acre-ft/yr). This runoff carried an estimated 126,000 tons ( 10,700 ton/yr) of suspended sediment into Highland Creek Reservoir. Total reservoir outflow for the study period was 188,700 acre-ft $(15,990$ acre-ft/yr), which carried 15,230 tons $(1,290$ ton/yr) of sediment. Particle size for both inflow and outflow sediment ranged from $<0.002 \mathrm{~mm}$ to 1.000 $\mathrm{mm}$. Approximately 96 percent of the sediment released from the reservoir consisted of particles smaller than $0.062 \mathrm{~mm}$. Estimated trap efficiency for the study period was 88 percent, based on the estimated sediment inflow and recorded sediment outflow.

Reservoir surveys made in December 1965 and A pril 1972 revealed a capacity loss of 35.8 acre-ft. Based on an estimated specific weight of $70 \mathrm{lb} / \mathrm{ft}^{3}, 54,600$ tons of sediment were deposited in the reservoir during the same 6.3-year period. The amount of sediment outflow from the reservoir during the same period was 8,890 tons. On the basis of the survey results and the recorded sediment outflow, the computed trap efficiency for the survey period was 86 percent.

\section{REFERENCES CITED}

Brune, G. M., 1953, Trap efficiency of reservoirs: Transactions of the American Geophysical Union, v. 34, no. 3, p. 407-418.

Colby, B. R., 1963, Fluvial sediment-a summary of source, transportation deposition, and measurement of sediment discharge: U.S. Geological Survey Bulletin 1181-A, p. $34-35$. 
Hansen, W. D., 1960, Rating curve for Highland Springs spillways: Lake County Flood Control and Water Conservation District, 6 p.

Lara, J. M., and Pemberton, E. L., 1965, Initial unit weight of deposited sediments: Proceedings of the Federal Interagency Sedimentation Conference, 1963: U.S. Department of Agriculture Miscellaneous Publications 970 , p. $818-845$.

McNitt, J. R., 1968, Geology of the Kelseyville quadrangle, Sonoma, Lake, and Mendocino Counties, California: California Division of Mines and Geology, Map sheet 9.

Rainwater, F. H., and Thatcher, L. L., 1960, Methods for collection and analysis of water samples: U.S. Geological Survey Water-Supply Paper 1454, 301 p.

U.S. Department of Agriculture, 1972, Reservoir sediment data sheet-Highland Creek Dam, Lake County, California: Soil Conservation Service data sheet no. 72 , 5 p.
U.S. Geological Survey, 1963-70, Surface water supply of the United States-Part 11, Pacific slope basins in California: U.S. Geological Survey Water-Supply Papers

1966-74, Water resources data for California-Part 2, Water quality records: U.S. Geological Survey.

U.S. Geological Survey, 1971-74, Water resources data for California-Part 1, Surface water records, v. 2, Northern Great Basin and Central Valley: U.S. Geological Survey.

1975-77, Water resources data for California, v. 4, Northern Central Valley basins and the Great Basin from Honey Lake basin to Oregon State line: U.S. Geological Survey Water-Data Records CA 75-4, CA 76-4, and CA 77-4.

U.S. Department of Commerce, 1967-77, Climatological Data-California: National Oceanic and Atmospheric Administration Environmental Data Service.

\section{Conversion Factors and Definitions}

The inch-pound system of units is used in this report. For readers who prefer metric units rather than inch-pound units, the conversion factors for the terms used in this report are listed below:

\begin{tabular}{|c|c|c|}
\hline Multiply & By & To obtain \\
\hline acres & 0.4047 & $\mathrm{hm}^{2}$ (square hectometers) \\
\hline acre-ft/(acre-feet) & 0.001233 & $\mathrm{hm}^{3}$ (cubic hectometers) \\
\hline $\begin{array}{l}\text { acre-ft } / \mathrm{yr} \text { (acre-feet } \\
\text { per year) }\end{array}$ & 0.001233 & $\begin{array}{l}\mathrm{hm}^{3} / \mathrm{yr} \text { (cubic hectometers } \\
\text { per year) }\end{array}$ \\
\hline $\mathrm{ft}($ feet $)$ & 0.3048 & $\mathrm{~m}($ meters $)$ \\
\hline $\begin{array}{l}\mathrm{ft}^{3} / \mathrm{s} \text { (cubic feet } \\
\text { per second) }\end{array}$ & 0.02832 & $\begin{array}{l}\mathrm{m}^{3} / \mathrm{s} \text { (cubic meters } \\
\text { per second) }\end{array}$ \\
\hline in (inches) & 25.4 & $\mathrm{~mm}$ (millimeters) \\
\hline $\begin{array}{l}\text { in } / \text { yr (inches } \\
\text { per year) }\end{array}$ & 25.4 & $\begin{array}{l}\mathrm{mm} / \mathrm{yr} \text { (millimeters } \\
\text { per year) }\end{array}$ \\
\hline $\begin{array}{l}\mathrm{lb} / \mathrm{ft}^{3} \text { (pounds per } \\
\text { cubic foot) }\end{array}$ & 16.02 & $\begin{array}{l}\mathrm{kg} / \mathrm{m}^{3} \text { ( } \text { kilograms per } \\
\text { cubic meter })\end{array}$ \\
\hline mi (miles) & 1.609 & km (kilometers) \\
\hline $\mathrm{mi}^{2}$ (square miles) & 2.590 & $\mathrm{~km}^{2}$ (square kilometers) \\
\hline tons (short) & 0.9072 & $\mathrm{Mg}$ (megagrams) \\
\hline ton/yr (tons per year) & 0.9072 & $\mathrm{Mg} / \mathrm{yr}$ (megagrams per year) \\
\hline ton/d (tons per day) & 0.9072 & $\mathrm{Mg} / \mathrm{d}$ (megagrams per day) \\
\hline
\end{tabular}

Abbreviations used

MG/L or mg/L (miligrams per liter)

MM or mm (millimeters)

$\mu \mathrm{MHO} / \mathrm{CM}$ (micromhos per centimeter)

DEG C or ${ }^{\circ} \mathrm{C}$ (degrees Celsius)

National Geodetic Vertical Datum of 1929 is a geodetic datum derived from the average sea level over a period of many years at 26 tide stations along the Atlantic, Gulf of Mexico, and Pacific Coasts and as such does not necessarily represent local mean sea level at any particular place. To establish a more precise nomenclature, the term "NGVD of 1929 " is used in place of "Sea Level Datum of 1929" or "mean sea level."

The water year is the 12-month period ending September 30 each year and is designated by the calendar year in which it ends and which includes 9 of the 12 months. 
